\begin{tabular}{|c|c|c|c|c|}
\hline & \begin{tabular}{|c|} 
Dose Q1 \\
21.00 to $13.75 \mathrm{mg}$ \\
$\mathrm{N}=184$ \\
\end{tabular} & \begin{tabular}{|c|} 
Dose Q2 \\
$>>13.75$ to $\leq 25.00 \mathrm{mg}$ \\
$\mathrm{N}=184$
\end{tabular} & \begin{tabular}{|c|} 
Dose Q3 \\
$>>25.00$ to $540.00 \mathrm{mg}$ \\
$\mathrm{N}=198$ \\
\end{tabular} & $\begin{array}{l}\text { Dose } Q 4 \\
>40 \mathrm{mg} \\
\mathrm{N}=161 \\
\end{array}$ \\
\hline $\begin{array}{l}\text { a aatients without type } 2 \text { diabetes and without } \\
\text { HbA1c } 7.5 \text { in the pre-index period, } \mathrm{n}\end{array}$ & 120 & 136 & 130 & 110 \\
\hline $\begin{array}{l}\text { Wilt type 2 2labetes diagnosis or HbA1c } 27.5 \\
\text { in the post-index period, } n(\%)\end{array}$ & $9(7.5)$ & $16(11.8)$ & $16(12.3)$ & $27(24.5)$ \\
\hline $\begin{array}{l}\text { Maximum HbA11 value eccosss HbA1c lab results } \\
\text { during post-index, mean (SD) }\end{array}$ & $7.75(2.46)$ & $8.30(2.86)$ & $825(2.42)$ & $8.61(3.09)$ \\
\hline $\begin{array}{l}\text { Pationts with diabotes diagnosis in the pre-index } \\
\text { period but without HoAlc } 27.5 \text { in the pre-index } \\
\text { period, n }\end{array}$ & 31 & 18 & 40 & 15 \\
\hline $\begin{array}{l}\text { With worsening diabetes with HbA Ac } 27.5 \text { in } \\
\text { the post-index period, } n(\%)\end{array}$ & $10(32.3)$ & $6(33.3)$ & $20(50.0)$ & $4(26.7)$ \\
\hline $\begin{array}{l}\text { Patients without blood glucose level } \geq 200 \mathrm{mg} / \mathrm{dL} \\
\text { in the previndex period, in } \\
\text { With blood glucose level } \geq 200 \mathrm{mo} / \mathrm{dL} \text { in the }\end{array}$ & & & 179 & 147 \\
\hline $\begin{array}{l}\text { With blood glucose level } \geq 200 \mathrm{mg} / \mathrm{dL} \text { in the } \\
\text { post-index period, } n(\%)\end{array}$ & $13(7.5)$ & $15(8.9)$ & $24(13.4)$ & $22(15.0)$ \\
\hline 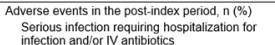 & $31(16.8)$ & $39(21.2)$ & $44(22.2)$ & $40(24.8)$ \\
\hline Serious infection requiring IV antibiotics & $29(15.8)$ & $33(17.9)$ & $42(21.2)$ & $35(21.7)$ \\
\hline $\begin{array}{l}\text { Serious infection requiring hospitalization } \\
\text { for infection }\end{array}$ & $6(3.3)$ & $12(6.5)$ & $12(6.1)$ & $8(5.0)$ \\
\hline $\begin{array}{l}\text { Cataracts } \\
\text { Gastrointest }\end{array}$ & $22(12.0)$ & $27(14.7)$ & $34(17.2)$ & $35(21.7)$ \\
\hline \begin{tabular}{|l} 
Gastrointestinal bleedng or ulcer \\
Patients with BMl in pre- and post-index, $n$
\end{tabular} & 1116 & $\frac{11(6.0)}{162}$ & $\frac{13(6.6)}{181}$ & $\frac{19(11.8)}{141}$ \\
\hline Increase in BMI by $5, \mathrm{n}(\%)$ & $7(41)$ & $5(3.1)$ & $9(5.0)$ & $9(6.4)$ \\
\hline
\end{tabular}

\section{FRI0273 SURVEYING PATIENTS WITH TAKAYASU ARTERITIS WITH A DELAYED DIAGNOSIS}

Irina Borodina', Artem Popov'. ' Ural State Medical University, hospital therapy, Yekaterinburg, Russian Federation; ${ }^{2}$ ural State Medical University, HOspital therapy, Yekaterinburg, Russian Federation

Background: Takayasu arteritis (TA) is a well known, but rarely identified variety of large vessel vasculitis. Frequency of initial misdiagnosing in TA patients has been reported to reach $80 \%$. Up to $80 \%$ of TA cases are correctly diagnosed only 2 to 11 years after the symptoms presentation. Objectives: to study possible reasons for misdiagnosing in TA patients with a delayed diagnosis.

Methods: cross-sectional survey included 30 TA patients. All subjects met ACR criteria for TA and more than 12 months since the onset of the clinical manifestations delayed diagnosis. The subjects were asked to recall if vessels auscultation (VA), measurement of both arms and legs blood pressure (BP), assessment of $\mathrm{BP}$ and pulse asymmetry (PA) were performed during their first physician visit following the symptoms onset. Results: $19(67 \%)$ patients reported no VA during the initial examination, only $3(10 \%)$ subjects confirmed the test performed, 5 (17\%) were not sure and $3(10 \%)$ did not apply for medical aid during the first year of the symptoms occurrence. Arms BP asymmetry was not assessed in 13 $(43 \%)$ patients, in $6(20 \%)$ subjects correct BP tests were performed, 8 $(27 \%)$ responders were not sure and $3(10 \%)$ had not consulted any physician timely. PA was assessed in7 $(23 \%)$ cases, PA was not tested in $12(40 \%)$ patients, and $8(27 \%)$ subjects were not sure. Arms and legs BP was not assessed in $26(87 \%)$ patients during their initial examination.

Conclusion: the data obtained confirm paramount importance of proper physical examination during initial physician's consultation for timely and correct Takayasu arteritis diagnosis.

\section{REFERENCES:}

[1] Arend W.P., Michel B.A., Bloch D.A., et al. The American College of Rheumatology 1990 criteria for the classification of Takayasu arteritis. Arthritis Rheum. 1990; 33(8): 1129-1134.

[2] PokrovskiI AV, Zotikov AE, Kul'bak VA, Burtseva EA. Problems of diagnostics and treatment strategy in patients with Takayasu' arteries. Vestn Ross Akad Med Nauk. 2010;(10):9-19.

[3] Ringleb PA, Strittmatter El, Loewer M, et al. Cerebrovascular manifestations of Takayasu Arteritis in Europe. Rheumatology 2005; 44 (8): 1012-5.

\section{Acknowledgement: accept}

Disclosure of Interests: None declared

DOI: 10.1136/annrheumdis-2019-eular.2781

\section{FRI0274 ULTRASOUND CUT-OFF VALUE FOR INTIMA-MEDIA THICKNESS OF THE AXILLARY ARTERIES IN PATIENTS WITH CHRONIC LARGE-VESSEL GIANT CELL ARTERITIS}

Philipp Bosch ${ }^{1}$, Christian Dejaco ${ }^{1,2}$, Wolfgang A. Schmidt ${ }^{3}$, Andreas Krause ${ }^{3}$, Kenny-Davis Schlüter ${ }^{3}$, Valentin S. Schäfer ${ }^{4} .{ }^{1}$ Medical University of Graz, Graz, Austria; ${ }^{2}$ Hospital of Bruneck, Bruneck, Italy; ${ }^{3}$ mmanuel Hospital Berlin, Berlin, Germany; ${ }^{4}$ University Hospital Bonn, Bonn, Germany

Background: The European League Against Rheumatism (EULAR) recently recommended the use of ultrasound for the detection of inflamed artery walls in giant cell arteritis (GCA) for diagnostic purposes. Intima media thickness (IMT) values, defining the "halo" sign in acute GCA patients, have also recently been proposed. In patients with chronic GCA, already receiving a treatment, the ultrasound appearance of inflamed artery walls changes and becomes difficult to detect.(1-4)

IMT measurement may help to identify patients with chronic large-vessel GCA (LV-GCA) by assessing the axillary arteries; however, a cut-off for distinguishing between chronically affected arteries and unaffected ones is not yet available.

Objectives: To determine an ultrasound IMT cut-off value for axillary arteries in patients with chronic LV-GCA.

Methods: Ultrasound of temporal and axillary arteries was performed in 127 GCA patients at the time of diagnosis and at one or two follow-up visits. Axillary arteries of GCA patients with sonographic signs of inflammation at the time of diagnosis were compared to unaffected axillary arteries of GCA patients and to axillary arteries of healthy controls. Receiver operating curves (ROC) were calculated using follow-up data to identify the optimal IMT cut-off.

Results: 148 axillary arteries of GCA patients showed signs of ultrasound inflammation at baseline (=LV-GCA group). The control group consisted of 162 axillary arteries, including $82(50.6 \%)$ axillary arteries of GCA patients without signs of ultrasound inflammation at baseline or follow-up exam and $80(49.4 \%)$ axillary arteries of 40 healthy controls. The mean age and gender distribution of the two groups at follow-up were 71 years (S D. 7.9) with $69.9 \%$ females, respectively in the chronic LV-GCA group and 74 years (S.D. 6.9) with $59.8 \%$ females, respectively in the control group. The mean IMT values in the LV-GCA group were 1.14 (S.D. $0.38, \mathrm{n}=78$ ) for the right and 1.18 (S.D. $0.47, \mathrm{n}=70$ ) for the left axillary arteries as compared to 0.60 (S.D. $0.11, \mathrm{n}=77$ ) for the right and 0.62 (S D. $0.11, n=85$ ) for the left axillary arteries in the control group. Intervals from diagnosis to follow-up were 0.5-3 years, 3-6 years and >6years, with a distribution of $96(65 \%), 32(22 \%)$ and $20(13 \%)$ exams in the LV-GCA group and 29 (35\%), $41(50 \%)$ and $12(15 \%)$ exams in the control group (excluding healthy controls), respectively.

The optimal IMT cut-off value for the axillary arteries in patients with chronic LV-GCA was $0.87 \mathrm{~mm}$ with $75.0 \%$ sensitivity and $99.4 \%$ specificity (see figure 1). Sensitivity analysis (comparing patients with and without an involvement of the temporal artery at the time of diagnosis) validated this cut-off value.

Conclusion: An ultrasound IMT cut-off value for the axillary arteries can distinguish between patients with chronic LV-GCA and patients without chronic large vessel involvement.

\section{REFERENCES :}

[1] Dejaco C, Ramiro S, Duftner C, et al. EULAR recommendations for the use of imaging in large vessel vasculitis in clinical practice. Ann Rheum Dis 2018;77:636-43.

[2] Schäfer VS, Juche A, Ramiro S, et al. Ultrasound cut-off values for intimamedia thickness of temporal, facial and axillary arteries in giant cell arteritis. Rheumatology 2017;56:1479-83.

[3] De Miguel E, Beltran LM, Monjo I, et al. Atherosclerosis as a potential pitfall in the diagnosis of giant cell arteritis. Rheumatology 2017;57:318-21.

[4] Czihal M, Schrottle A, Baustel K, et al. B-mode sonography wall thickness assessment of the temporal and axillary arteries for the diagnosis of giant cell arteritis: a cohort study. Clin Exp Rheumatol 2017;35 Suppl 103:12833.

ROC curve for axillary artery cut-off

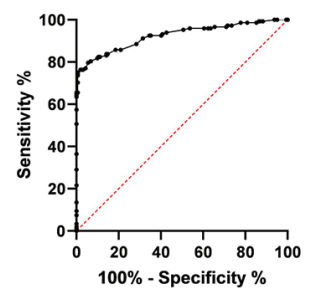

Figure. 1. Receiver operating curve for the axillary artery cut-off in chronic large-vessel giant cell arteritis.

Disclosure of Interests: Philipp Bosch: None declared, Christian Dejaco Speakers bureau: MSD, Pfizer, UCB, AbbVie, Roche, Novartis, Lilly, Celgene, Merck, Sandoz, Wolfgang A. Schmidt: None declared, Andreas Krause Consultant for: Pfizer, Speakers bureau: Pfizer, Kenny-Davis Schlüter: None declared, Valentin S. Schäfer: None declared DOI: 10.1136/annrheumdis-2019-eular.3252 